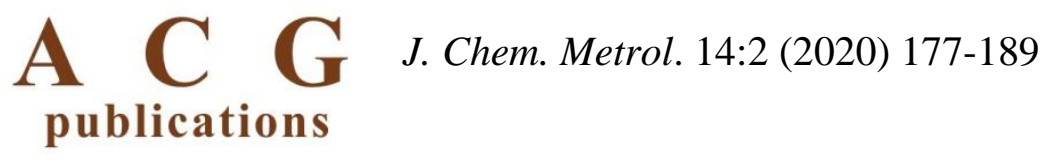

journal of chemical metrology

\title{
A Year - round motoring of ambient volatile organic compounds across Dardanelles strait ${ }^{\S}$
}

\author{
Sibel Mentese ${ }^{*}$ and Batuhan Bas \\ Çanakkale Onsekiz Mart University, Faculty of Engineering, Environmental Engineering Department, \\ Çanakkale, Türkiye
}

(Received September 22, 2020; Revised November 24, 2020; Accepted November 25, 2020)

\begin{abstract}
Dardanelles strait has a crucial importance on marine transport, splitting Çanakkale city. Combustionrelated anthropogenic sources emit volatile organic compounds (VOCs) into the air and they have public concern due to adverse health effects. In this study, composition of ambient VOCs across Dardanelles strait was monitored for 4 seasons over the year of 2018. A total of 12 sampling locations, including 5 locations on the European and 7 locations on the Asian seashores of Dardanelles strait were determined as sampling points. Standard methods were followed during the sampling and analysis of VOCs. VOCs samples were collected on thermal desorber tubes, containing sorbents of Tenax TA and Carbograph 1TD. Active VOC samples were collected by an air sampling pump and passive VOCs samples were exposed to air for 2 weeks. VOCs samples were analyzed by Thermal Desorber followed by Gas Chromatography - Flame Ionization Detector. Target VOCs in this study were paraffins and aromatic hydrocarbons. Limit of quantification was assessed as $\leq 0.1 \mu \mathrm{g} / \mathrm{m}^{3}$. According to the results of the study, VOCs concentrations varied both spatially and seasonally. The most abundant VOCs in the air were $n$ pentane, $n$-hexane, toluene, benzene, and 1,2,4-trichlorobenzene throughout the study. Furthermore, the highest VOCs levels mostly occurred at the locations that were close to the traffic sources and/or residential areas.
\end{abstract}

Keywords: Ambient air pollution; Çanakkale; Dardanelles strait; gas chromatography; thermal desorption; volatile organic compounds. () 2020 ACG Publications. All rights reserved.

\section{Introduction}

Ambient air pollution has been one of the most prominent global issues and the linkage between poor air quality and cancer has been declared recently [1]. One of the most studied air pollutant groups I volatile organic compounds (VOCs), originated mostly from human activities. Also, reactive VOCs can trigger photochemical smog reactions in the atmosphere [2].

VOCs compose of compounds from very volatile to semi-volatile range and the most frequent ones are alkanes, benzene derivatives, and alkenes [3]. The fact that plenty sources of VOCs are available, type and quantity of the VOC specie in the air varied spatially and temporally. In several studies, higher VOCs levels were observed in the winter than summer [4-6]. At ambient temperatures, VOCs easily produce mostly odorous vapors (pungent or good smell). [7]. Many VOCs are also classified as 'air toxics' due to

\footnotetext{
* Corresponding author E-Mail: sibelmentese@gmail.com

$\S$ The study was presented in 10th NationalAnalytical Chemisty Congress in Muğla Turkey 
their adverse health effects and known or potential carcinogenecity Industrial processes and vehicle emissions are the dominant sources of outdoor VOCs in the United States [8].

Both national and international marine transports have been contribution on transit passages across the Dardanelles Strait. The fact that approximately 240 ships are crossing the Dardanelles strait on a daily basis, ship emissions have a considerable contribution on the city air quality [9], which was pointed out by Mentese and Akça [10]. In terms of pollutant generation per fuel consumed, ship emissions have the highest emission factor [11]. Large ship crossings have a substantial contribution on air pollution (VOCs, Carbon monoxide, Nitrogen oxides, Sulfur oxides, particulate matter, etc.) both inland and transboundary areas [12-14].

Dardanelles strait divides Çanakkale province into two parts, which lay on the Anatolian and European sides. Dardanelles strait has a crucial importance on marine transport, not only on a national basis, but also in terms of remarkable number of international transit passages [10]. Domestic heating and both road and marine traffic have been shown as major sources of ambient air pollution of Çanakkale $[10,15]$. Also, relatively strong northern winds together with other meteorological parameters influence the air quality by transportation of the air plumes over the city [16]. Contribution of ship emissions on local air quality have been documented in several regions of Turkey [17-21].

The aims of this study were to find $i$ ) spatial and $i$ ) seasonal variations of target VOCs throughout Dardanelles strait. For this aim, composition of ambient VOCs across Dardanelles strait was monitored for 4 seasons over the year of 2018. A total of 12 sampling locations, including 5 locations on the European and 7 locations on the Asian seashores of Dardanelles strait were determined as sampling sites. Standard test methods were followed during sampling and analysis of VOCs. Target VOCs in this study were paraffins and aromatic hydrocarbons.

\section{Experimental}

VOCs samples were collected from the ambient air of 12 different sampling points laid on both European and Asian sides of Dardanelles strait, Çanakkale, Turkey. VOCs samples were collected for consecutive 4 seasons, starting from winter period.

\subsection{Samplig Sites}

Çanakkale city is located on the western part of Turkey and has parts both on Asian (As) and European (Eu) continents, split by Dardanelles strait. Currently, Çanakkale Central town and Çanakkale city have populations of 175.032 and 540.662 people, respectively [22].

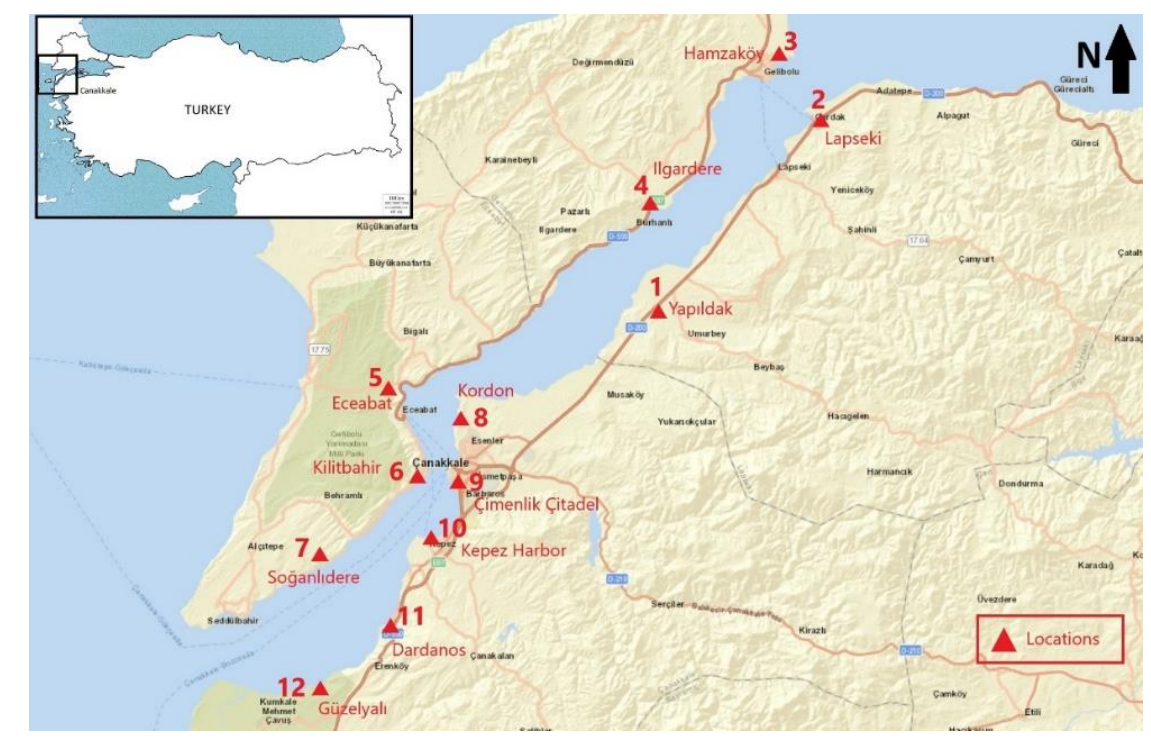

Figure 1. Locations of the sampling sites (1-Yapıldak, 2-Lapseki, 3-Hamzakoy, 4-Ilgardere, 5-Eceabat, 6-Kilitbahir, 7-Soganlıdere, 8-Kordon, 9-Çimenlik citadel, 10-Kepez Harbor, 11-Dardanos, 12 Güzelyal1). 
This study was conducted over the seashore of Dardanelles strait both on the Asian and European sides. The locations of the sampling points are given in Figure 1. VOCs samples were taken from a total of 12 samplings sites laid on both sides of Dardanelles strait. Sampling sites of $3-7$ laid on the European side, while sampling sites of $1-2$ and 8 - 12 laid on the Asian side of Dardanelles strait, which are 1Yapildak (As), 2-Lapseki (As), 3-Hamzakoy (Eu), 4-Ilgardere (Eu), 5-Eceabat (Eu), 6-Kilitbahir (Eu), 7Soganl1dere (Eu), 8-Kordon (As), 9-Çimenlik citadel (As), 10-Kepez Harbor (As), 11-Dardanos (As), and 12-Güzelyalı (As).

Selection of the study route was mainly considered according to traffic flows: $i$ ) due to road traffic of local people who regularly commuted on the main roads of the city and ii) the traffic due to the high number of commuters who loaded their vehicles into the ferries at any of the Çanakkale harbors (i.e. Çanakkale, Kepez, Kilitbahir, Eceabat, Gelibolu, Lapseki, Çardak, Kabatepe, and Geyikli harbors).

\subsection{Sampling and Analysis of VOCs Samples}

Air samples were taken in 4 seasons of the year of 2018 from 12 sampling points across Dardanelles strait. Sampling schedule was as follows: winter sampling was in February 2018; spring sampling was in May 2018; summer sampling was in July 2018, and fall sampling was in November 2018. A total of 2 active samples and 1 passive sample were collected from each sampling point in each season, The first sample of the active sampling campaign was drawn in the beginning of the sampling month and the second sample was drawn in the middle of the month. Passive samples were kept in the sampling sites throughout the first second and active sampling periods (i.e. 14 days). Active VOCs samples were drawn according to active sampling principle given in United States Environmental Protection Agency (US EPA) TO17 Method [23]. Air samples were taken in stainless steel thermal desorber tubes, containing Tenax TA (a porous polymer, 35/60 mesh) and Carbograph 1TD (a graphitized Carbon Black, 40/60 mesh), with a total of approx. $350 \mathrm{mg}$ mass of sorbents (Markes Inc., UK). The fact that both sorbents are hydrophobic, water and moisture handling were achieved while taking samples at humid environments [24].

Thermal desorber tubes were conditioned for 2 hours at $320{ }^{\circ} \mathrm{C}$ followed by $30 \mathrm{~min}$ at $335^{\circ} \mathrm{C}$ desorption conditions using carrier gas of extra pure Nitrogen at a flow rate of $100 \mathrm{~mL} / \mathrm{min}$, as suggested by the thermal desorber tube supplier. Cleaned tubes were capped with $1 / 4$ inch brass storage caps fitted with $1 / 4$ inch combined PTFE ferrules. Conditioned tubes were stored in a clean refrigerator prior to sampling and desorption. VOCs samples were collected by a low-flow air sampling pump (SKC Inc., pocket pump, model 210-1003MTX) with the total volume of approx. $5 \mathrm{~L}$ (volume of the air sampled = air flow rate $\mathrm{x}$ sampling duration).

At the preliminary test stage, single tube, dual tube, and triple tube options were tested for the samples collected for different air sampling duration and air sampling flow options while performing the breakthrough tests. Final air sampling flow rate was set as $75 \mathrm{~mL} / \mathrm{min}$, calibrated with a digital flow controller (DryCal Defender 510) and sampling duration was around 1 hour. Air samples were drawn under the atmospheric pressure condition. Details regarding the repeatability, reproducibility, and stability of the air flow calibration studies are explained in Supporting Information. Collected VOC samples were kept in a clean carry bag, including conditioned activated charcoal and silica gel against crosscontamination during the shipping.

Collected VOCs samples were then analyzed by Gas Chromatography Flame Ionization Detector (GC-FID, Agilent Inc., 7890A, USA) followed by Thermal Desorber (Unity 2 \& Ultra100, Markes Inc., UK). Sorbent tubes were fitted with DiffLock caps for thermal desorption analysis. Thermal desorption technique has currently been the primary method recommended by ISO, EN, US EPA, NIOSH, ASTM, Chinese EPA, and UK Environment Agency, etc. [23,25-34]. Used analytical technique in this study has several advantages: Thermal desorption technique, based on adsorption principle where volatile compounds in the air are adsorbed on the selected sorbents, whereas in chemical extraction technique volatile samples are adsorbed mostly on activated charcoal and extracted in Carbon disulfide $\left(\mathrm{CS}_{2}\right)$, which was also confirmed as a quantitative analysis technique for semi- and other volatile organic compound by NIOSH, Method-2549 [25]. Also, potential risk from $\mathrm{CS}_{2}$ use by laboratory workers is of concern due to 
its potential adverse health effects [35]. Thermal desorption technique eliminates contaminations stemming from the technician and the extract solution, since target volatiles are directly transferred to GC inlet in gaseous phase by transfer line connected between the outlet of thermal desorber and inlet of GC. Details regarding the thermal desorption technique can be found in Woolfenden \& Poole [36]. Overall, thermal desorption methods had better repeatability, recovery, and detection and quantification limit than those of the solvent extraction methods [37-38]. Thermal desorber used in this study cools the sample temperature down to $-15{ }^{\circ} \mathrm{C}$ electronically, therefore no need to use liquid nitrogen for cooling purpose. It was suggested by the thermal desorber tube supplier that the maximum desorption temperature must be around $300-320{ }^{\circ} \mathrm{C}$ to reduce the artefacts and extend sorbent lifetime. Therefore, desorption temperatures of 250 to $300{ }^{\circ} \mathrm{C}$ and desorption times from $3 \mathrm{~min}$ to $15 \mathrm{~min}$ were tested for estimation of the best desorption efficiency. Finally, desorption at $300^{\circ} \mathrm{C}$ for $10 \mathrm{~min}$ was found as optimum desorption condition.

High purity Hydrogen, Nitrogen, and dry air were used as GC gases. A GC capillary column of DB-VRX $(75 \mathrm{~m} \times 0.45 \mathrm{~mm} \times 2.55 \mu \mathrm{m})$ was used to separate target VOCs. Details regarding the GC temperature program is as follows: initial $40^{\circ} \mathrm{C}$ for $5 \mathrm{~min}$, ramp to $220^{\circ} \mathrm{C}$ at $5{ }^{\circ} \mathrm{C} / \mathrm{min}$, hold $10 \mathrm{~min}$ for a total run time of $51 \mathrm{~min}$. The heaviest target compound of the study was $n$-hexadecane with a boiling point of $286.9^{\circ} \mathrm{C}$.

VOC standard solutions (VOC + Unsaturated Organic Compounds Mix 1, Dr. Ehrenstorfer \& Piano-Paraffins, Supelco) were used to qualify and quantify the individual VOC species by 7 - points calibration curve $\left(\mathrm{r}^{2}>0.99\right)$. Calibration standard solutions were loaded by using calibration loading ring (Markes Inc., CSLR, UK) with approximately $50 \mathrm{~mL} / \mathrm{min}$ of extra pure Nitrogen as a carrier gas. $1 \mu \mathrm{lof}$ calibration standard solution was injected into the conditioned thermal desorber tubes with a gas tight micro-syringe (Agilent Inc., Golden syringe). Signal to noise ratio of the runs was over 3 for the chromatograms of standard solutions which had the lowest mass amount [39].

Details regarding the repeatability, reproducibility, and linearity of the calibration studies are explained in Supporting Information. Method detection limit (MDL) of the individual VOC species was computed as less than $0.1 \mu \mathrm{g} / \mathrm{m}^{3}$ according to the US EPA method [40]. For every 10 samples, 1 laboratory and 1 field blanks were analyzed and no significant (cross) - contamination was found in the blank samples. VOC samples were put in a clean container, including conditioned activated charcoal and silica gel and stored in the fridge till the analysis. Analysis of the VOC samples were conducted no later than 3 days after the sampling. In terms of Quality Assurance/Quality Control (QA/QC) procedures, relevant standards were used for the sampling, analyzing, and quantification of the VOCs [23,41-42].

In addition to active samplings carried out for 4 seasons, passive (diffusive) VOC samples were collected for 4 seasons. The same sampling tubes were used and a diffusive cap (Markes Inc.) placed on top of the one side of the tube was exposed to air for 2 weeks at each sampling point. For this aim, ISO 16017-2 [27] was followed as a standard method to quantify the target VOC species in the sampled air. BTEX levels were calculated based on the equation derived from Fick's First Law of diffusion (See Suppl. Information). Also, concentration of total volatile organic compounds (TVOC) from $n$-hexane to $n$ hexadecane was calculated equivalent to toluene response [16,43]. VOC concentrations found in the passive samples were given in Supporting information file, Table S2.

\subsection{Meteorological Parameters}

Atmospheric temperature $\left({ }^{\circ} \mathrm{C}\right)$ and relative humidity $(\mathrm{RH}, \%)$ values were measured with a realtime thermal hygrometer (Testo $174 \mathrm{H}$, Germany) throughout the sampling. Also, atmospheric Carbon dioxide $\left(\mathrm{CO}_{2}\right)$ level $(\mathrm{ppm})$ was measured by a real-time instrument (Testo 435-2, Germany) with resolution of $1 \mathrm{ppm}$, based on infrared radiation (IR). $\mathrm{CO}_{2}$ measurement was carried out merely in the winter and spring sampling periods, while data was unavailable for the summer and fall periods due to an instrumentational error.

\subsection{Data Evaluation}

Descriptive statistics shown in the figures and tables are computed based on the average value of two active air samples collected in each sampling season from all sampling points. Box-Whisker plots 
were used to visualize the temporal and spatial distribution of the data set. ANOVA test was utilized for searching the differences among group means in a sample. For all applied tests, values with $p<0.05$ were considered statistically significant. Spearman rank correlation test was used to estimate the correlations among the measured VOCs. No outlier was observed in the VOCs concentration dataset.

\section{Results and Discussion}

\subsection{Meteorological Parameters Over the Study Period}

Atmospheric temperature, $\mathrm{RH}$, and $\mathrm{CO}_{2}$ levels over the sampling period are given in Table 1 . Accordingly, seasonal average values of air temperature, $\mathrm{RH}$, and $\mathrm{CO}_{2}$ were over $9.7^{\circ} \mathrm{C}, 38 \%$, and 447 ppm, respectively.

Table 1. Meteorological parameters throughout the sampling period*

\begin{tabular}{lccc}
\hline Season & Temperature $\left({ }^{\mathbf{0}} \mathbf{C}\right)$ & RH $(\%)$ & $\mathbf{C O}_{2}$ concentration $(\mathbf{p p m})$ \\
\hline Fall & $12.7 \pm 1.4(10.3-14.5)$ & $63.6 \pm 7.9(54-83)$ & NA \\
Winter & $9.7 \pm 2.2(8.1-12.3)$ & $51.1 \pm 11.5(31.0-71.0)$ & $514.1 \pm 112.1(364-919)$ \\
Spring & $28.9 \pm 3.6(23.9-36.4)$ & $46.6 \pm 7.0(34.059 .0)$ & $447 \pm 70(366-629)$ \\
Summer & $35.3 \pm 3.1(31.6-42.3)$ & $38.3 \pm 6.1(30-53)$ & NA \\
\hline
\end{tabular}

"Data is given as average \pm standard deviation $(\min -\max )$ was given in parenthesis ; NA: Not available.

\subsection{Yearly Average Levels of VOCs at all Sampling Sites}

Observation frequency $(\%)$ and concentrations $\left(\mu \mathrm{g} / \mathrm{m}^{3}\right)$ of aromatic compounds, halogenated organic compounds, and paraffins measured at all sampling points throughout the year are given in Tables $2-4$, respectively. Also, variation of concentrations of target compounds according to the sampling season and site found by ANOVA tests are given in the tables.

Table 2. Observation frequency $(\%)$ and concentrations of aromatic compounds $\left(\mu \mathrm{g} / \mathrm{m}^{3}\right)$ measured at all sampling points throughout the year and concentration variations of the compounds according to the sampling season and site

\begin{tabular}{|c|c|c|c|c|}
\hline \multirow{2}{*}{ Aromatic compounds } & \multirow{2}{*}{ Frequency $(\%)$} & \multirow{2}{*}{ Concentration $\left(\mu \mathrm{g} / \mathrm{m}^{3}\right)$} & \multicolumn{2}{|c|}{ Significance } \\
\hline & & & season & site \\
\hline benzene & 100 & $1.7 \pm 0.9$ & $* *$ & \\
\hline toluene & 100 & $3.2 \pm 1.9$ & $* *$ & \\
\hline ethylbenzene & 93.8 & $0.4 \pm 0.2$ & $*$ & \\
\hline$m, p$-xylene & 97.9 & $1.2 \pm 0.8$ & & \\
\hline$o$-xylene & 91.7 & $0.5 \pm 0.4$ & & $*$ \\
\hline styrene & 100 & $0.4 \pm 0.4$ & & $*$ \\
\hline isopropylbenzene & 85.4 & $0.6 \pm 1.1$ & & \\
\hline$n$-propylbenzene & 93.8 & $0.8 \pm 0.4$ & & \\
\hline 1,3,5-trimethylbenzene & 72.9 & $1.1 \pm 1.1$ & & \\
\hline tertiary-butylbenzene & 58.3 & $0.9 \pm 1.6$ & & \\
\hline 1,2,4-trimethylbenzene & 85.4 & $0.9 \pm 0.8$ & $*$ & \\
\hline 4-isopropyltoluene & 37.5 & $0.4 \pm 0.6$ & & \\
\hline$n$-butylbenzene & 25.0 & $0.5 \pm 0.4$ & $*$ & \\
\hline naphthalene & 93.8 & $0.5 \pm 0.4$ & & \\
\hline
\end{tabular}

Note: Concentration values are shown as average \pm standard deviation; statistically significant differences at ${ }^{*} p<0.05$ and ${ }^{* *} p<0.001$ significance levels were estimated between the locations or seasons, $\mathrm{n}=48$. 
As can be seen from Table 2, benzene, toluene, and styrene occurred in all samples (100\% of observation frequency). Other target aromatic hydrocarbons had $25.0 \%$ ( $n$-butylbenzene) to $97.9 \%$ ( $m, p$ xylene) observation frequency of $100 \%$. In terms of abundance in the ambient air, toluene (annual avg. of $3.2 \mu \mathrm{g} / \mathrm{m}^{3}$ ) and benzene (annual avg. of $1.7 \mu \mathrm{g} / \mathrm{m}^{3}$ ) had the highest concentrations throughout the year. Levels of benzene, toluene, ethylbenzene, 1,2,4-trimethylbenzene, and $n$-butylbenzene showed seasonal variations over the year $(p<0.05)$. Also, $o$-xylene and styrene levels were found to be different at the sampling sites $(p<0.05)$.

BTEX compounds are associated with the photochemical age of the ambient air and/or the exhaust emissions from the traffic $[44,45]$. BTEX levels were found to be lower in another study conducted around Çanakkale and Kilitbahir harbors [10].

According to Table 3, bromobenzene and 1,2,4-trichlorobenzene were seen in all samples (observation frequency of 100\%). Other target halogenated organic compounds had $8.3 \%$ (hexa-chloro1,3,-butadiene) to $95.8 \%$ (1,2,3-trichlorobenzene) observation frequencies. In terms of abundance in the ambient air, 1,2,4-trichlorobenzene (annual avg. of $3.7 \mu \mathrm{g} / \mathrm{m}^{3}$ ) and 4-chlorotoluene (annual avg. of 2.1 $\mu \mathrm{g} / \mathrm{m}^{3}$ ) had the highest concentrations throughout the year. Levels of 4-chlorotoluene, 1,4dichlorobenzene, and 1,2,4-trichlorobenzene showed seasonal variations over the year $(p<0.05)$. Also levels of bromobenzene showed statistically significant variations among the sampling sites $(p<0.05)$.

According to Table 4, $n$-pentane, $n$-octane, and $n$-undecane occurred in all samples (observation frequency of $100 \%$ ). Other target alkanes had $41.7 \%$ ( $n$-dodecane) to $97.9 \%$ ( $n$-hexane and $n$-hexadecane) observation frequencies. In terms of abundance in the ambient air, $n$-pentane (annual avg. of $8.2 \mu \mathrm{g} / \mathrm{m}^{3}$ ) and $n$-hexane (annual avg. of $3.5 \mu \mathrm{g} / \mathrm{m}^{3}$ ) had the highest concentrations throughout the year. Levels of $n$ pentane, $n$-hexane, and $n$-tetradecane showed seasonal variations over the year $(p<0.05)$. Also levels of $n$-nonane showed statistically significant variations among the sampling sites $(p<0.05)$.

Table 3. Observation frequency $(\%)$ and concentrations of halogenated organic compounds $\left(\mu \mathrm{g} / \mathrm{m}^{3}\right)$ measured at all sampling points throughout the year and concentration variations of the compounds according to the sampling season and site

\begin{tabular}{lcccc}
\hline \multirow{2}{*}{ Halogenated Compounds } & Frequency $(\boldsymbol{\%})$ & $\begin{array}{c}\text { Concentration } \\
\left(\boldsymbol{\mu g} / \mathbf{m}^{\mathbf{3}}\right)\end{array}$ & \multicolumn{2}{c}{ Significance } \\
\cline { 5 - 6 } & & $1.0 \pm 1.1$ & & $*$ \\
\hline sec-butylbenzene ${ }^{\mathrm{a}}+1,3$-dichlorobenzene & 58.3 & $1.0 \pm 0.6$ & & $*$ \\
bromobenzene & 100 & $1.9 \pm 1.3$ & & \\
2-chlorotoluene & 70.8 & $2.1 \pm 1.4$ & $*$ & \\
4-chlorotoluene & 83.3 & $0.8 \pm 0.9$ & $*$ & \\
1,4-dichlorobenzene & 31.3 & $0.5 \pm 0.6$ & & \\
1,2-dichlorobenzene & 33.3 & $3.7 \pm 4.4$ & $*$ & \\
1,2,4-trichlorobenzene & 100 & & & \\
hexa-chloro-1,3-butadiene & 8.3 & $0.4 \pm 0.1$ & & \\
1,2,3-trichlorobenzene & 95.8 & $1.3 \pm 0.6$ & & \\
\hline
\end{tabular}

Note: Concentration values are shown as average \pm standard deviation; statistically significant differences at ${ }^{*} p<0.05$ and ${ }^{* *} p<0.001$ significance levels were estimated between the locations or seasons, $\mathrm{n}=48$

${ }^{a}$ showed as total concentration of sec-butylbenzene and 1,3-dichlorobenzene here.

Associations among the individual VOCs measured in this study were examined with Spearman rank correlation. Merely, compounds with high observation frequency and high abundance were considered in the analysis. As can be seen from Table 5, strong to weak correlations were found for the selected compounds $(p<0.05)$. Correlated compound pairs based on the highest correlation coefficients $(\mathrm{r})$ with statistical confidence at $p<0.001$ ranked as follows: toluene $-n$-hexane $(\mathrm{r}=0.76), m, p$-xylene -4 chlorotoluene $(\mathrm{r}=0.61)$, benzene - toluene $(\mathrm{r}=0.59)$, benzene $-m, p$-xylene $(\mathrm{r}=0.59)$, benzene $-n$ hexane $(\mathrm{r}=0.56)$, and $n$-pentane -4 -chlorotoluene $(\mathrm{r}=0.54)$. Also, moderate to weak correlations were found for other compound pairs $(r<0.50$ and $p<0.05)$. Similarly, strong correlations between BTEX compounds were found in other studies, indicating same source contributor(s) such as traffic [10,44-50]. 
Table 4. Observation frequency $(\%)$ and concentrations of paraffins $\left(\mu \mathrm{g} / \mathrm{m}^{3}\right)$ measured at all sampling points throughout the year and concentration variations of the compounds according to the sampling season and site

\begin{tabular}{lccc}
\hline \multirow{2}{*}{ Paraffins } & Frequency $(\boldsymbol{\%})$ & $\begin{array}{c}\text { Concentration } \\
\left(\boldsymbol{\mu g} / \mathbf{m}^{\mathbf{3}}\right)\end{array}$ & \multicolumn{2}{c}{ Significance } \\
\cline { 3 - 5 }$n$-pentane & 100 & $8.2 \pm 0.5$ & $* *$ \\
$n$-hexane & 97.9 & $3.5 \pm 2.0$ & $* *$ \\
$n$-heptane & 95.8 & $0.7 \pm 0.4$ & \\
$n$-octane & 100 & $1.0 \pm 0.7$ & \\
$n$-nonane & 95.8 & $0.6 \pm 0.6$ & \\
$n$-decane & 81.3 & $1.0 \pm 2.3$ & \\
$n$-undecane & 100 & $0.9 \pm 0.9$ & \\
$n$-dodecane & 41.7 & $0.3 \pm 0.4$ & \\
$n$-tridecane & 52.1 & $0.3 \pm 0.2$ & \\
$n$-tetradecane & 72.9 & $0.4 \pm 0.3$ & \\
$n$-pentadecane & 93.8 & $0.5 \pm 0.5$ & \\
$n$-hexadecane & 97.9 & $0.8 \pm 0.5$ & \\
\hline
\end{tabular}

Note: Concentration values are shown as average \pm standard deviation; statistically significant differences at $* p<0.05$ and $* * p<0.001$ significance levels were estimated between the locations or seasons, $\mathrm{n}=48$.

Table 5. Associations among the most frequent compounds with high abundances: Spearman rank correlation

\begin{tabular}{|c|c|c|c|c|c|c|c|c|}
\hline Compound & benzene & toluene & $m, p-X$ & $\mathrm{C}_{5}$ & $\mathrm{C}_{6}$ & 2-Cl-toluene & 4-Cl-toluene & 1,2,4-tri-Cl-benzene \\
\hline benzene & 1 & & & & & & & \\
\hline toluene & $0.59 * *$ & 1 & & & & & & \\
\hline$m, p-\mathrm{X}$ & $0.59 * *$ & $0.30 *$ & 1 & & & & & \\
\hline $\mathrm{C}_{5}$ & 0.01 & 0.01 & $0.37 *$ & 1 & & & & \\
\hline $\mathrm{C}_{6}$ & $0.56 * *$ & $0.76 * *$ & 0.21 & -0.26 & 1 & & & \\
\hline 2-Cl-toluene & 0.23 & -0.12 & 0.24 & 0.34 & -0.19 & 1 & & \\
\hline 4-Cl-toluene & 0.29 & -0.04 & $0.61 * *$ & $0.54 * *$ & -0.14 & $0.40 *$ & 1 & \\
\hline 1,2,4-tri-Cl-benzene & 0.09 & -0.03 & 0.13 & 0.01 & -0.09 & 0.31 & $0.39 *$ & 1 \\
\hline
\end{tabular}

Note: $\mathrm{X}$ : xylene, $\mathrm{Cl}$ : chloro, $\mathrm{C}_{5}: n$-pentane, $\mathrm{C}_{6}: n$-hexane; correlated pairs at $* p<0.05$ and $* * p<0.001$ significance; correlation coefficient of $r>0.50$ are shown bold; $n=48$.

\subsection{Seasonal Variations of VOCs}

Seasonal variations of measured VOCs were assessed for priority pollutants with statistically significant seasonal variations (see Table 1). Figure 2 shows the seasonal variations of sum of benzene, toluene, ethylbenzene, and xylenes (BTEX), benzene, toluene, and $m, p$-xylene levels measured at all sampling points over the year. In terms of levels of sum of BTEX, benzene, and toluene $(p<0.05)$, the highest concentrations were observed in fall season, while the lowest concentrations were observed in the spring. Unlikely, $m, p$-xylene levels were found to be higher and varied in broad ranges both in the spring and the winter and the lowest levels were seen in the summer. However, seasonal variation of $m, p$-xylene was insignificant $(p>0.05)$. VOCs levels showed seasonal variations in another study conducted in Ankara [51]. 

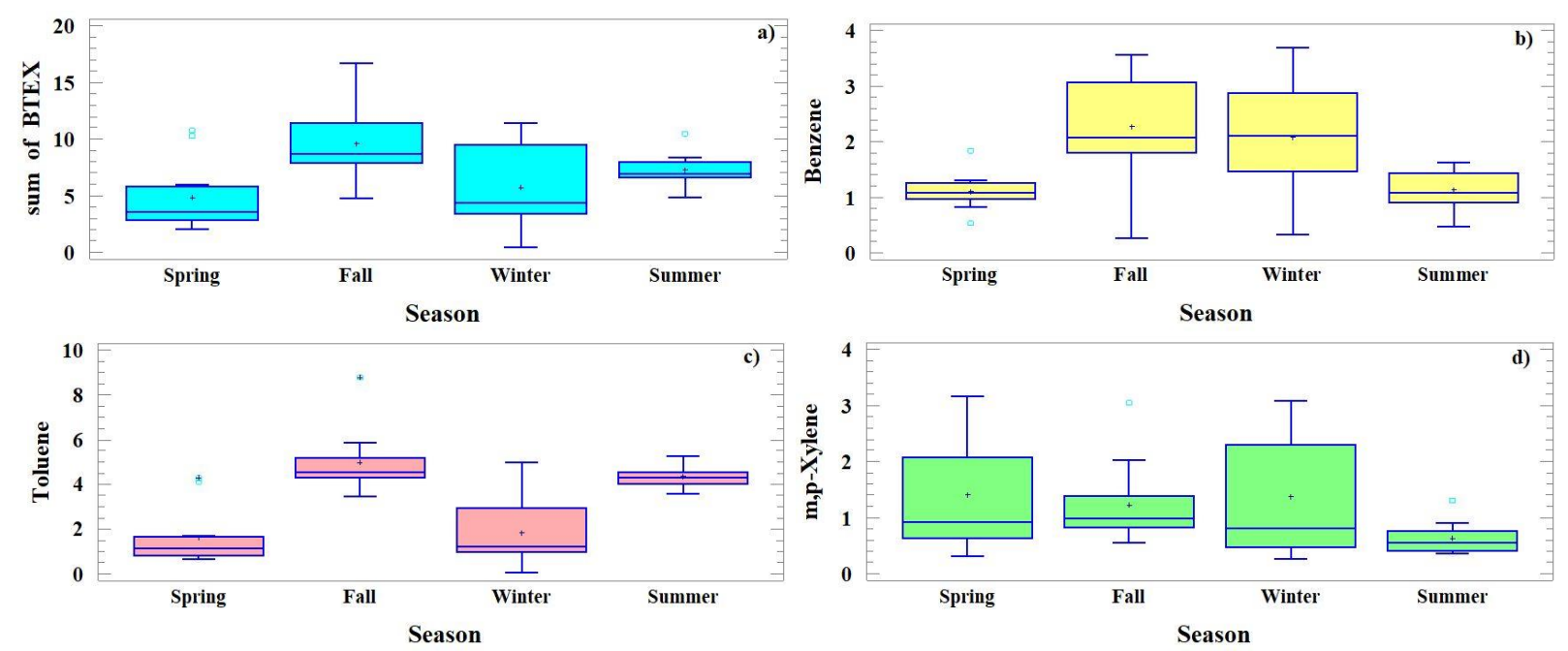

Figure 2. Seasonal variations of levels of a) sum of $\operatorname{BTEX}(p<0.01)$, b) benzene $(p<0.001)$, c) toluene $(p<0.001)$, and d) $m, p$-xylene $(p>0.05)$

(匹: Q1 - Q3, $\mathrm{T}$ and $\perp$ : upper and lower confidence levels within 1.5 inter quartile range (IQR), - : median, and + : average)

\subsection{Spatial Variations of VOCs over the Dardanelles Strait}

Concentrations of VOCs at the sampling points were investigated. Figure 3 shows the spatial variations of sum of BTEX, benzene, toluene, and $m, p$-xylene levels among the sampling points measured for 4 seasons. The highest concentrations concerning those compounds were found at Çimenlik citadel, located at the downtown of Çanakkale city center. Therefore, both marine and road traffic as well as human activities might have influenced the abundance of VOCs around Çimenlik citadel. The lowest median levels were observed at Ilgardere and Eceabat for sum of BTEX; at Soganlidere for benzene; and at Ilgardere, Soganlidere, and Yapildak for $m, p$-Xylene. The common characteristics of Ilgardere, Yapildak, and Soganlidere can be listed as follows: $i$ ) far from the potential anthropogenic air pollution sources such as on road traffic and traffic due to the laden of the vehicles into the ferryboats and ii) relatively less air pollutant emissions due to domestic heating, as limited number of residential settings are available around those regions. Toluene levels were found to be close to each other at the sampling points, except for Çimenlik citadel. In another study conducted in Çanakkale city, average values for total BTEX compounds were $15.4 \mu \mathrm{g} / \mathrm{m}^{3}$ in Kilitbahir and $29 \mu \mathrm{g} / \mathrm{m}^{3}$ in Çanakkale and BTEX levels showed statistically significant differences between the two sites [10].

\subsection{Seasonal Variations of VOCs over the Dardanelles Strait}

Seasonal variations of VOCs were estimated at the statistical significance level $(p)$ of 0.05 , as given in Tables 1 - 3. Among the compounds that showed significant seasonal variations, seasonal variations of the most frequent and abundant ones, including benzene, toluene, $n$-pentane, $n$-hexane, and 1,2,4-trichlorobenzene at 12 sampling points are shown in Figure 4. Within the context of the target compounds of this study, benzene was classified as a carcinogenic to human beings [52]. Therefore, the maximum acceptable limit value at the ambient air has been set by many countries and international organizations such as World Health Organization (WHO) and European Union (EU). Similar to other countries, national limit value for benzene was set as $5 \mu \mathrm{g} / \mathrm{m}^{3}$ as annual average by Turkish Air Pollution 

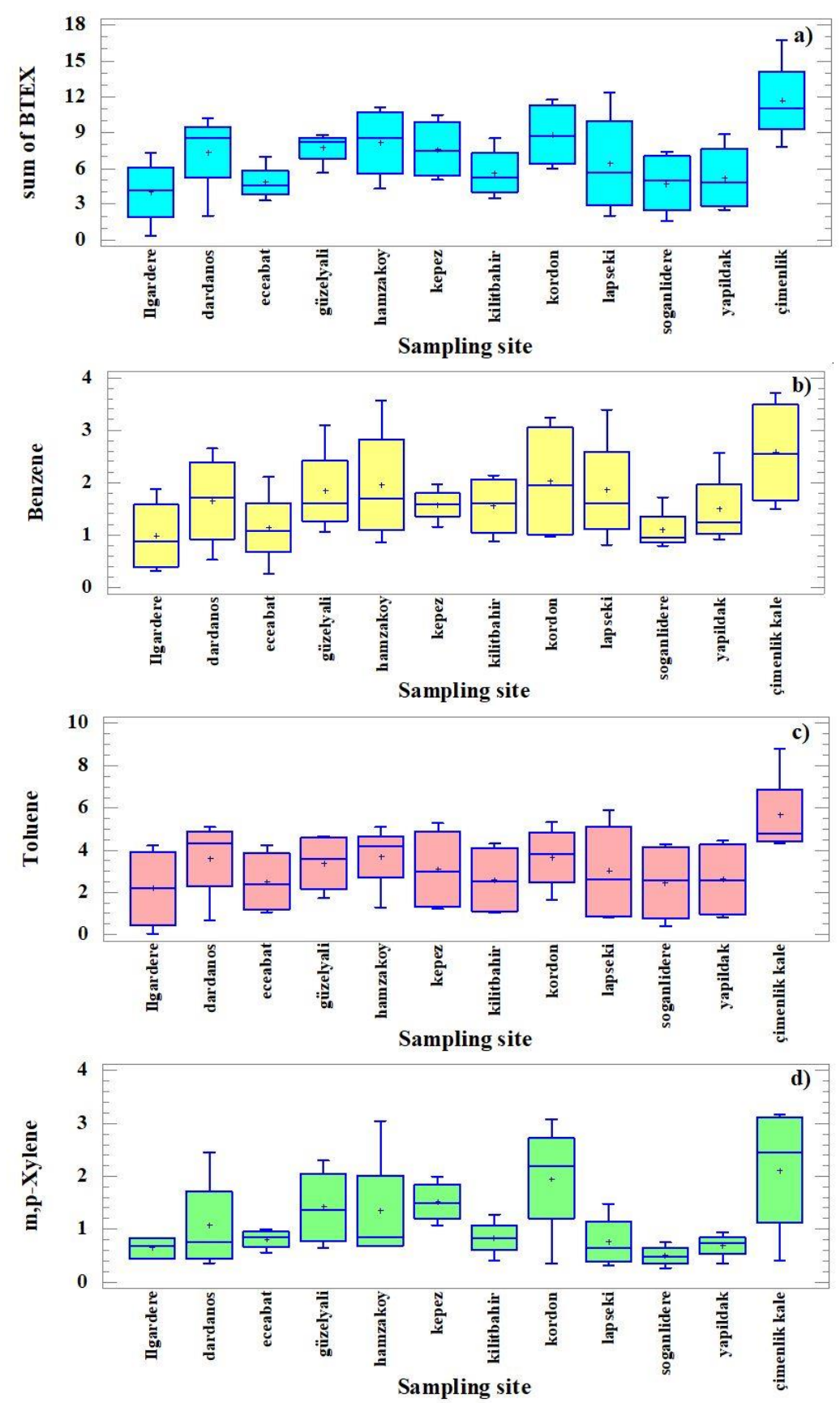

Figure 3. Spatial variations of levels of a) sum of BTEX $(p<0.05)$, b) benzene $(p>0.05)$, c) toluene $(p>0.05)$, and d) $m, p$-xylene ( $p>0.05$ ) levels among the sampling sites measured over the year

Control and Evaluation Regulation [53]. As can be seen from Figure 4a, benzene levels did not exceed the annual average limit value of $5 \mu \mathrm{g} / \mathrm{m}^{3}$. However, winter-time benzene levels were as high as $6 \mu \mathrm{g} / \mathrm{m}^{3}$ at Kordon and Çimenlik citadel, considered as downtown of the city center, indicating the contribution of anthropogenic activities to occurred benzene levels. Similarly, the highest levels of toluene, $n$-pentane, $n$ hexane, and 1,2,4-trichlorobenzene were observed at Kordon and Çimenlik citadel. In terms of the seasonal change of the most abundant VOCs: benzene occurred in the winter and fall; toluene occurred in the fall and summer; $n$-pentane occurred in the spring; $n$-hexane occurred in the fall, except for the peak $n$-hexane level observed at Kordon in the winter; and no clear seasonal trend was observed for 1,2,4trichlorobenzene, while the peak level of 1,2,4-trichlorobenzene was observed at Çimenlik citadel in the winter. 

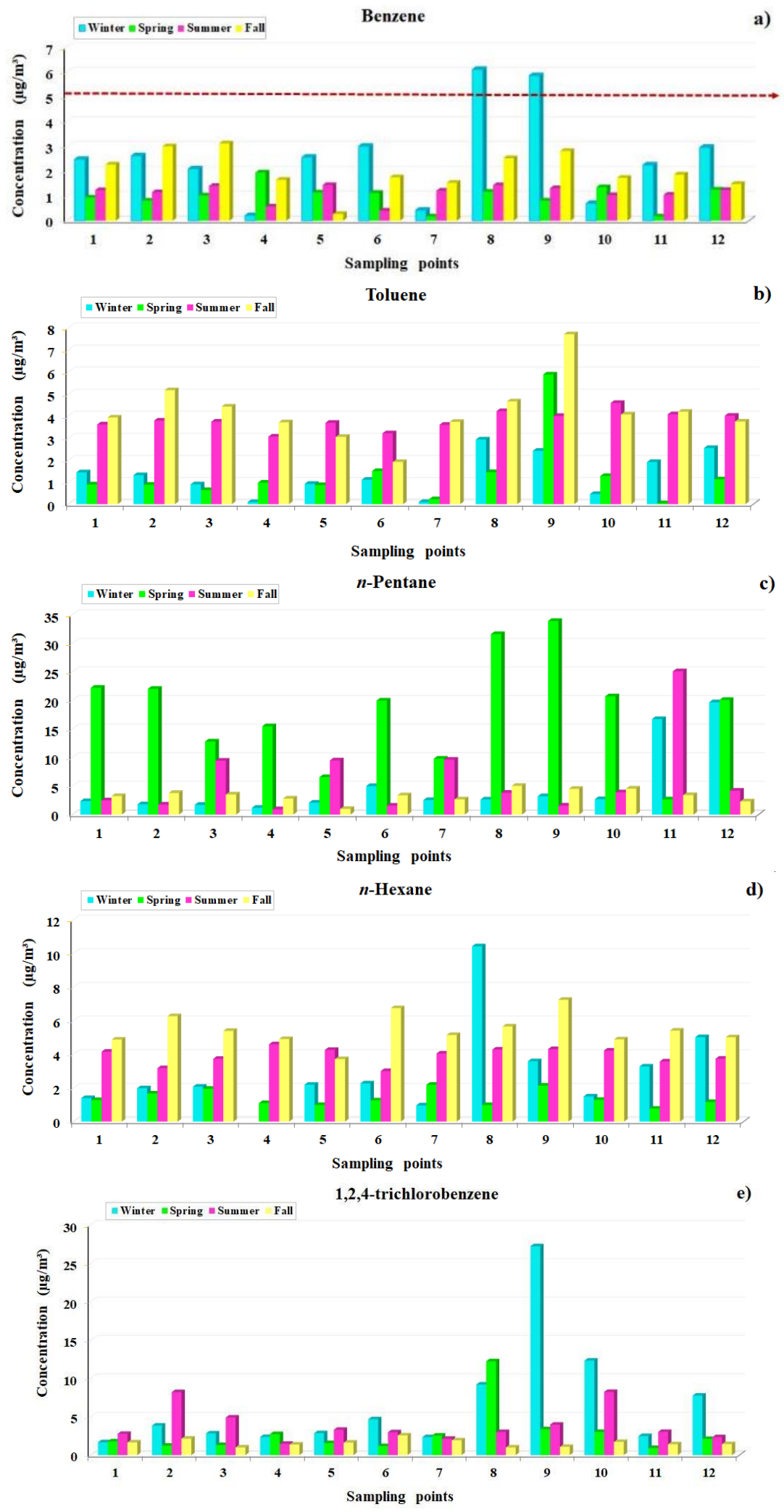

Figure 4. Seasonal variations of concentrations of a) Benzene, b) Toluene, c) $n$-Pentane, d) $n$-Hexane, and e) 1,2,4-trichlorobenzene at the sampling points ( $p<0.05$ for each compound)

(sampling points: 1-Yapildak, 2-Lapseki, 3-Hamzakoy, 4-Ilgardere, 5-Eceabat, 6-Kilitbahir, 7Soganlidere, 8-Kordon, 9-Çimenlik citadel, 10-Kepez Harbor, 11-Dardanos, 12-Güzelyal1). 
In this study, high VOCs levels were observed either the locations close to the traffic sources or dense residential settings. A previous study conducted in Çanakkale also pointed out the major sources of VOCs as traffic [10]. Traffic sources had major contributions on ambient VOCs levels [44-56]. In addition to typical on-road traffic, traffic related to maritime transportation had contribution on the air pollutant levels of Çanakkale. Due to its geopolitical position, the Dardanelles Strait is one of the major transit waterway in the world for both national and international marine transportation [10]. Earlier researches showed that large ship crossings caused significant air pollution issues and marine transport emissions released variety of air pollutants globally, such as sulfur oxides ( $\mathrm{SOx}$ ), nitrogen oxides (NOx), particulate matter, including diesel particles, heavy metals, and VOCs [14,56-60]. However, majority of the studies that estimated VOCs exposure of the people around the harbors are not based on the measurement results.

\section{Conclusions}

In this study, composition of ambient VOCs across Dardanelles strait was monitored at 12 sampling locations for 4 seasons over the year. Standard test methods were followed during sampling and analysis of VOCs. According to the results of the study, VOCs concentrations varied both spatially and seasonally. The most abundant VOCs in the air were toluene, benzene, $n$-pentane, $n$-hexane, and 1,2,4trichlorobenzene over the study. Briefly, the highest levels of benzene occurred in the winter; toluene occurred in the fall and summer, xylenes occurred in the summer, and ethylbenzene occurred in the spring and summer. Overall, the highest VOCs levels were mostly found at the locations that were close to the traffic sources and/or residential areas.

\section{Acknowledgements}

This study was partially supported by Çanakkale Onsekiz Mart University, Scientific Research Unit, Project no: FAY-2017-1281. Authors also thank Ekrem Yusuf Uludag and Bahar Akca for field studies.

\section{Supporting Information}

Supporting information accompanies this paper on http://www.acgpubs.org/journal/ journalof-chemical-metrology

\section{ORCID}

Sibel Mentese: 0000-0002-0395-3603

Batuhan Bas: $\underline{0000-0002-7188-7484}$

\section{References}

[1] World Health Organization (WHO) (2014). Media Centre. Ambient (outdoor) air quality and health, Fact sheet No: 313. http://www. who.int/mediacentre/factsheets/fs313/en/ (Access date: 5 July 2015).

[2] H.B. Singh and P. Zimmerman (1992). Atmospheric distributions and sources of nonmethane hydrocarbons. In: Nriagu, J.O. (Editor), Gaseous Pollutants: Characterisation and Cycling. Wiley, New York, pp. 235.

[3] S. Mentese (2009). Investigation of Indoor Air Quality and Determination of Their Sources. Hacettepe University, Institute of Science, Ph.D. thesis.

[4] G. Gilli, R. Bono and E. Scursatone (1990). Volatile halogenated hydrocarbons in urban atmosphere and in human blood, Arch Environ. Health. 45, 101-106.

[5] H.C. Shields, D.M. Fleischer and C.J. Weschler (1996). Comparisons among VOCs measured in three types of U.S. commercial buildings with different occupant densities, Indoor Air 6, 2-17.

[6] M. Rehwagen, U. Schlink and O. Herbarth (2003). Seasonal cycle of VOCs in apartments, Indoor Air 13, $283-291$.

[7] E. Dudley, M. Yousef, Y. Wang and W.J. Griffiths (2010). Chapter 2 - Targeted metabolomics and mass spectrometry, Adv. Protein Chem. Struct. Biol. 80, 45-83.

[8] US EPA (2019). Hazardous Air Pollutants, https://www.epa.gov/haps (accessed: Oct 2019). 
Ministry of Transport and Infrastructure of Turkish Republic (2019). Marine Trade Statistics of 2018. http://www.ubak.gov.tr/BLSM_WIYS/DTGM/tr/Kitaplar/20161116_165220_64032_1_64480.pdf～(accessed: 11.05.2019).

[10] S. Mentese and B. Akça (2020). Hot-spot summertime levels and potential sources of volatile organic compounds (VOC) on roads around Çanakkale and Kilitbahir harbors across Dardanelles strait, Atmos. Pollut. Res 11, $2297-$ 2307.

[11] J.J. Corbett and P.S. Fischbeck (1997). Emissions from Ships, Science 278(5339), 823-824.

[12] J.J. Corbett and A.L. Robinson (2001). Measurement of NOx emissions and in-service duty cycle from a towboat operating on the inland river system, Environ. Sci. Technol. 35, 1343-1349.

[13] J.J. Corbett and A. Farrell (2002). Mitigating air pollution impacts of passenger ferries, Transportat. Res. Part D 7, 197-211.

[14] C. Deniz and Y. Durmusoglu (2008). Estimating shipping emissions in the region of the Sea of Marmara, Turkey, Sci. Total Environ. 390, 255-261.

[15] S. Mentese, N.A. Mirici, T. Elbir, G.T. Tuygun, C. Bakar, M.T. Otkun and S. Oymak (2020). A comprehensive assessment of ambient air quality in Çanakkale city: emission inventory, air quality monitoring, source apportionment, and respiratory health indicators, Atmos. Pollut. Res 11, 2282-2296.

[16] S. Mentese, C. Bakar, N.A. Mirici, S. Cevizci and M.T. Otkun (2018). Associations between respiratory health and ambient air quality in Canakkale, Turkey: a long term cohort study, Environ. Sci. Pollut. Res. 25, 12915-12931.

[17] U. Kesgin and N. Vardar (2001). A study on exhaust gas emissions from ships in Turkish Straits, Atmos. Environ. 35, 1863-1870.

[18] A. Kilic and C. Deniz (2010). Inventory of Shipping Emissions in Izmit Gulf, Turkey, Environ. Prog. Sustain. Energy 29(2), 221-232.

[19] C. Deniz, A. Kilic and G. Civkaroglu (2010). Estimation of shipping emissions in Candarli Gulf, Turkey, Environ. Monit. Assess. 171, 219-228.

[20] C. Deniz and A. Kilic (2010). Estimation and assessment of shipping emissions in the region of Ambarlı port, Turkey, Environ. Prog. Sustain. Energy 29(1), 107-115.

[21] H. Saraçoğlu, C. Deniz and A. Kılıç (2013). An invenstigation on the effects of ship sourced emissions in Izmir port, Turkey, The Scient. J. Article ID 218324, 8 pages.

[22] Turkish Statistical Institute (2020). Populations of Çanakkale Province and its towns. http://www.turkstat.gov.tr/UstMenu.do?metod=temelist (accessed: October 8, 2020).

[23] US EPA (1999). Compendium Method for the Determination of Organic Compounds in Ambient Air TO-17. EPA/625/R-96010b.

[24] M. de la Guardia and S. Armenta (2016). The Quality of Air, Volume 73, 1st Edition, Elsevier, p.1000.

[25] NIOSH Method 2549 (1996). Volatile Organic Compounds (Screening), NIOSH.

[26] ISO 16017-1 (2000). Indoor, ambient and workplace air -- Sampling and analysis of volatile organic compounds by sorbent tube/thermal desorption/capillary gas chromatography - Part 1: Pumped sampling, Geneva, ISO.

[27] ISO 16017-2 (2003). Indoor, ambient and workplace air -- Sampling and analysis of volatile organic compounds by sorbent tube/thermal desorption/capillary gas chromatography - Part 2: Diffusive sampling, Geneva, ISO.

[28] EN 14662-4 (2005). Ambient Air Quality - Standard Method for Measurement of Benzene Concentrations - Part 4: Diffusive Sampling Followed By Thermal Desorption And Gas Chromatography, EN.

[29] Chinese EPA Method HJ 644 (2013). Volatile organic compounds - Ambient air Determination of volatile organic compounds Sorbent adsorption and thermal desorption / gas chromatography mass spectrometry HJ 644-2013.

[30] Chinese EPA Method HJ 734 (2014). Volatile organic compounds - Stationary source emission: Determination of volatile organic compounds Sorbent adsorption and thermal desorption gas chromatography mass spectrometry method HJ 734-2014.

[31] UK Environment Agency (2014). Method LFTGN 04, Monitoring trace components in landfill gas: LFTGN 04.

[32] CEN/TS 13649 (2014). Stationary source emissions. Determination of the mass concentration of individual gaseous organic compounds. Sorptive sampling method followed by solvent extraction or thermal desorption, CEN.

[33] US EPA (2015). Method 325B - Volatile Organic Compounds from Fugitive and Area Sources, US EPA.

[34] ASTM D-6196 (2015). Standard Practice for Choosing Sorbents, Sampling Parameters and Thermal Desorption Analytical Conditions for Monitoring Volatile Organic Chemicals in Air, ASTM.

[35] V. Frost-Barnes (2017). A Review of Carbon Disulfide-GC/FID Versus Thermal Desorption-GC/MS Methods Through the Lens of Analytical Proficiency and Human and Environmental Health Risk. Graduate Theses \& NonTheses. 111.

[36] E. Woolfenden and C. Poole (2012). Thermal desorption for gas chromatography. In Gas Chromatography (First Edition, pp. 236-257). Elsevier.

[37] N. Ramírez, A. Cuadras, E. Rovira, F. Borrull and R.M. Marcé (2010). Comparative study of solvent extraction and thermal desorption methods for determining a wide range of volatile organic compounds in ambient air, Talanta 82(2), 719-727.

[38] J.W. Kim, Y.-M. Kim, H.M. Moon, A. Hosaka, C. Watanabe, N. Teramae and S.-W. Myung (2016). Comparative study of thermal desorption and solvent extraction-gas chromatography-mass spectrometric analysis for the quantification of phthalates in polymers. J. Chromatogr. A 1451, 33-40.

[39] G. Wells, H. Prest and C.W. Russ (2011). Signal, noise, and detection limits in mass spectrometry. Technical Note, Chemical Analysis Group, Agilent Technologies.

[40] US EPA (2016). Definition and Procedure for the Determination of the Method Detection Limit, Revision 2. https://www.epa.gov/sites/production/files/2016-12/documents/mdl-procedure_rev2_12-13-2016.pdf 
[41] European Collaborative Action-IAQ (ECA) (1997). Total volatile organic compounds TVOC in indoor air quality investigations [Report No. 19]. Brussels: European Commission.

[42] ISO 16017-1 (2000). Indoor, ambient and workplace air sampling and analysis of volatile organic compounds by sorbent tube/thermal desorption/capillary gas chromatography e Part 1: pumped sampling. Geneva: ISO.

[43] ISO 16000-6. Determination of volatile organic compounds in indoor and test chamber air by active sampling on Tenax TA sorbent, thermal desorption and gas chromatography using MS/FID, indoor, ambient and workplace air sampling and analysis of volatile organic compounds by sorbent tube/thermal desorption/capillary gas chromatography e Part 1: pumped sampling. Geneva: ISO; 2004.

[44] B. Barletta, S. Meinardi, F.S. Rowland, C.Y. Chan, X. Wang, S. Zou, L.Y. Chan and D.R. Blake (2005). Volatile organic compounds in 43 Chinese cities, Atmos. Environ. 39(32), 5979-5990.

[45] L. Miller, L. D. Lemke, X. Xu, S. M. Molaroni, H. Y. A. J. Wheeler, J. Booza, A. Grgicak-Mannion, R. Krajenta, P. Graniero, H. Krouse, L. Lamerato, D. Raymond, J. Reiners and L. Weglicki (2010). Intra-urban correlation and spatial variability of air toxics across an international airshed in Detroit, Michigan (USA) and Windsor, Ontario (Canada), Atmos. Environ. 44(9), 1162-1174.

[46] R.R. Hoque, P.S. Khillare, T. Agarwal, V. Shridhar and S. Balachandran (2008). Spatial and temporal variation of BTEX in the urban atmosphere of Delhi, India, Sci. Total Environ. 392(1), 30-40.

[47] A. J. Buczynska, A. Krata, M. Stranger, A.F. Locateli Godoi, V. Kontozova-Deutsch, Lç Bencs, I. Naveau, E. Roekens and R. van Grieken (2009). Atmospheric BTEX-concentrations in an area with intensive street traffic, Atmos. Environ. 43(2), 311-318.

[48] V.T.Q. Truc and N.T.K. Oanh (2007). Roadside BTEX and other gaseous air pollutants in relation to emission sources, Atmos. Environ. 41(36), 7685-7697.

[49] H.D. Rad, A.A. Babaei, G. Goudarzi, K.A. Angali and M.M. Mohammadi (2014). Levels and sources of BTEX in ambient air of Ahvaz metropolitan city, Air Qual. Atmos. Health 7, 515-524.

[50] M. Miri, M. R. A. Shendi, H. R. Ghaffari, H. E. Aval, E. Ahmadi, E. Taban, A. Gholizadeh, M. Y. Aval, A. Mohammadi and A. Azari (2016). Investigation of outdoor BTEX: Concentration, variations, sources, spatial distribution, and risk assessment, Chemosphere 163, 601-609.

[51] S. Menteşe, A.Y. Rad, M. Arisoy and G. Gullu (2012). Multiple comparisons of organic, microbial, and fine particulate pollutants in typical indoor environments: Diurnal and seasonal variations, J. Air Waste Manag. Assoc. 62, 1380-1393.

[52] International Agency for Research on Cancer (IARC) (1987). Overall Evaluations of Carcinogenicity. IARC Monographs on the Evaluation of Carcinogenic Risk of Chemicals to Humans, Supplement 7. Lyon, France.

[53] HKDYY (Turkish Air Quality Assessment and Management Regulation), 2008. OJ date: 06.06.2008 issue: 26898.

[54] M.I. Khoder (2007). Ambient levels of volatile organic compounds in the atmosphere of Greater Cairo, Atmos. Environ. 41(3), 554-566.

[55] J. Liu, Y. Mu, Y.Zhang, Z. Zhang, X. Wang, . Liu and Z.Sun (2009). Atmospheric levels of BTEX compounds during the 2008 olympic games in the urban area of Beijing, Sci. Total Environ. 408(1), 109-116.

[56] K.F. Ho, S.C. Lee, H. Guo and W.Y. Tsai (2004). Seasonal and diurnal variations of volatile organic compounds (VOCs) in the atmosphere of Hong Kong, Sci. Total Environ. 322(1-3), 155-166.

[57] J.G. Edinger, M.H. McCutchan, P.R. Miller, B.C. Ryan, M.J. Shroeder and J.V. Behar (1979). Penetration and duration of oxidant air pollution in the South Coast Air Basin of California, J. Air Pollut. Control Assoc. 22, 882 886.

[58] X.M. Wang, G. Y. Sheng, J.M. Fu, C.Y. Chan, S.C. Lee, L. Y. Chan and Z. S. Wang (2002). Urban roadside aromatic hydrocarbons in three cities of the Pearl River Delta, People's Republic of China, Atmos. Environ. 36(33), 51415148 .

[59] V. Eyring, I. S.A. Isaksen, T. Berntsen, W.J. Collins, J. J. Corbett, O.Endresen, R. G. Grainger, J. Moldanova, H. Schlager and D. S. Stevenson (2010). Transport impacts on atmosphere and climate: Shipping, Atmos. Environ. 44(37), 4735-4771.

[60] D. Mueller, S. Uibel, M. Takemura, D. Klingelhoefer and D.A. Groneberg (2011). Ships, ports and particulate air pollution - an analysis of recent studies, J. Occup. Med. Toxicol. 6, Article number: 31.

[61] F. Alver, B.A. Saraç and Ü.A. Şahin (2018). Estimating of shipping emissions in the Samsun Port from 2010 to 2015, Atmos. Pollut. Res. 9, 822-828.

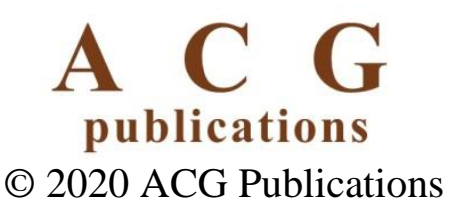

